\title{
The Iberian Middle Jurassic carbonate-platform system: Synthesis of the palaeogeographic elements of its eastern margin (Spain)
}

\author{
J.J. Gómez ${ }^{\text {a,* }}$, S.R. Fernández-López ${ }^{\mathrm{b}}$ \\ ${ }^{\text {a }}$ Dpto. Estratigrafia, Facultad de Ciencias Geológicas (UCM) e Instituto de Geologia Económica, (CSIC-UCM), 28040 Madrid, Spain \\ ${ }^{\mathrm{b}}$ Dpto. Paleontologia, Facultad de Ciencias Geológicas (UCM) e Instituto de Geología Económica, (CSIC-UCM), 28040 Madrid, Spain
}

\begin{abstract}
During the Middle Jurassic, the domain of the Iberian and Catalan Coastal ranges of eastern Spain was occupied by a system of fault-controlled carbonate platforms that flanked the Iberian Massif to the East. This platform system marked the transition between the shelves of the Alpine Tethys and the Central Atlantic Ocean. The palaeogeographic reconstruction of the Iberian Middle Jurassic platform system is based on more than 199 surface sections and 37 wells. From southwest to northeast, eight main palaeogeographic elements with associated characteristic facies are recognized. These represent a system of horsts and grabens. In the southwest, the Internal Castilian Platform is characterized by the frequently dolomitized oolitic and restricted facies of the Yemeda Formation. To the northeast, the NW-trending open-marine carbonate environments of the External Castilian and Aragonese platforms were separated by the fault-controlled El Maestrazgo High that is characterized mainly by the dolomitized Rafales Formation. The External Castilian and Aragonese platforms consist from bottom to top of the microfilament mudstones to wackestones of the El Pedregal Formation, the bioclastic and oolitic grainstones to packstones of the Moscardon Formation, and the Domeño Formation, that reflects a return to an open-marine low-energy wackestone to mudstone facies, locally containing patches of oolitic grainstones. The highly subsiding Tortosa Platform, represented by the Sant Blai, Cardo and La Tossa formations, is bounded by the dolomitic facies deposited on the El Maestrazgo and the Tarragona highs, and by the Catalan Massif where no Middle Jurassic deposits have been recorded. The open-marine facies and condensed sections of the Beceite Strait separated the Aragonese and Tortosa platforms. A regional stratigraphical gap spanning the upper Callovian Lamberti Zone to the lower Oxfordian Cordatum Zone is evident. A system of northwest- and northeast-trending normal faults controlled thickness and facies distribution. Data from the Iberian carbonate-platform system indicate that expanded sections were not necessarily associated with open-marine environments. Condensed and expanded sections are developed in open and restricted-marine facies, even on such palaeogeographic highs as the El Maestrazgo High. Restricted and shallow-marine environments occasionally developed in parts of the External Castilian Platform.
\end{abstract}

Keywords: Middle Jurassic; Carbonate platforms; Stratigraphy; Palaeoenvironments; Palaeogeography; Spain

\footnotetext{
* Corresponding author. Tel.: +34 913944783; fax: +34 913944808.

E-mail addresses: jgomez@geo.ucm.es (J.J. Gómez), sixto@geo.ucm.es (S.R. Fernández-López).
}

\section{Introduction}

Regional Middle Jurassic palaeogeographic reconstructions of the early opening stage of the Central Atlantic Ocean and the Alpine Tethys indicate that the East-Iberian area was occupied by a carbonate-plat- 
form system, the facies development and subsidence patterns $\bullet$ which were controlled by active faults (Fig. 1; Ziegler, 1990; Bassoullet et al., 1993; Enay et al., 1993; Thierry, 2000; Vera, 2001, 2004; Vera et al., 2001; Stampfli and Berel, 2004).

In the fold-and-thrust belts of the Iberian and Catalan Coastal ranges of Spain, which evelved by $\mathrm{Pa}-$ leøgene inversion of Mesøzıic rifted basins (Salas et al., 2001), Middle Jurassic carbonates are exposed under •utstanding •utcrop conditions over a distance -f more than $500 \mathrm{~km}$. In the context of $\bullet$ ur studies, we analysed in these areas 199 Middle Jurassic surface sections and data from 37 borehøles (Fig. 2). This permitted us to develop a detailed reconstruction of the palae@ge日graphic elements of the East-Iberian Middle Jurassic carbonate-platform system. In the Iberian Range, Middle Jurassic carbonates, formerly attributed to the "middle portion" of the Chelva Formation (Gómez and Gøy, 1979), were recently subdivided inte several lithostratigraphic units (Gómez and Fernández-López, 2004a,b) on the basis -f their distinct facies development that can be related

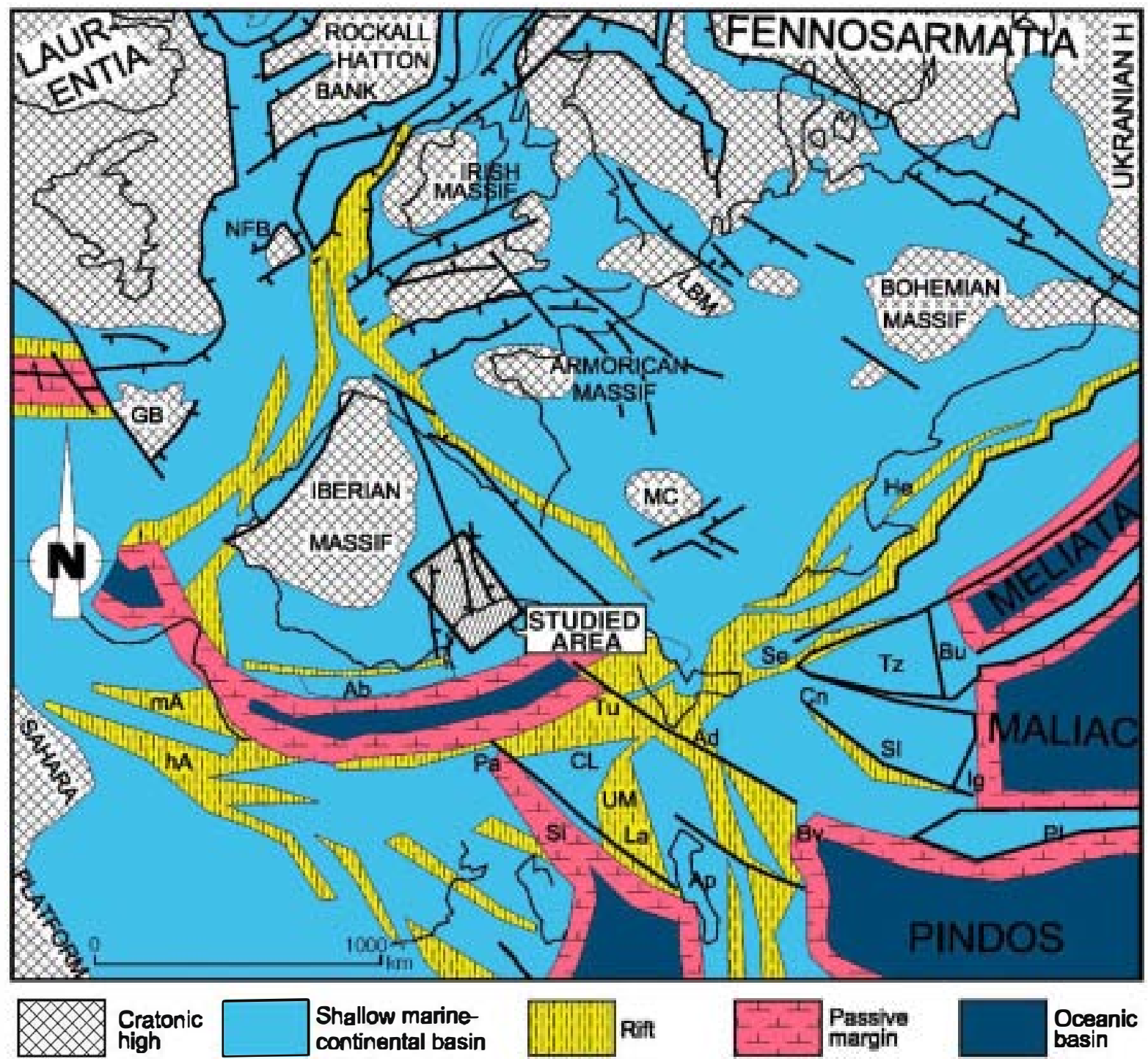

Fig. 1. Middle Jurassic palaeogeography of the Westem Tethys and the Proto-Atlantic Ocean (Ziegler, 1990; Stampfli and Borel, 2004; modified) and location of the studied area. Ab: Alboran. Ad: Adria s. str. Ap: Apulia s. str. Bu: Bucovinian. CL: Campania Lucania. Cn: Carnic-julian. GB: Grand Bank. hA: High Atlas. He: Helvetic rim basin. Ig: Igal rough. La: Lagonegro. LBM: London-Braband Massif. mA: Middle Atlas. MC: Massif Central High. NF B: East Newfoundland Basin. Pa: Panornides. Pl: Pelagonian. Se: Sesia (westem Austroalpine). Si: Sicanian. S1: Slavonia. Tu: Tuscan. Tz: Tizia. UM: Umbria-Marches. 
to their palaenge grapbic setting (Fig. 3). In the Catalan Coastal Range, Cadillac et al. (1981) and Fernández-López et al. (1996, 1998) had analysed the lithøstratigraphy of Middle Jurassic depøsits. Detailed

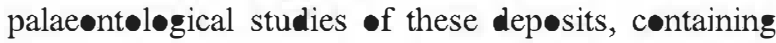
ammønites, alløwe for a high-resølution biøstratigraphic subdivision of this sequence at the scale of zones, subzones and horizons (Hinkelbein, 1975; Gómez, 1979; Fernández-López, 1985; Meléndez, 1989). In this study, biostratigraphical data are referred to the standard zones of ammonites.

During the Middle Jurassic, the s-called Iberian Basin was $\bullet c c u p i e$ by a complex system of epicontinental carbonate platforms that in many cases were tectonically controlled. Up-thrown blocks formed palae ge graphic highs that were characterize by shalløw-water depositional envirønments. Areas between these highs were largely dominated by open-marine envirønments, under which low-energy fossil-rich ammonite-bearing facies developed, suggesting that they were partly connected to the open $\bullet$ cean (Aurell et al., 2002, 2003; Fernández-López and Gómez, 2004). Frøm southwest to northeast, eight main palae@gegraphic elements can be recøgnized that were assøciated with characteristic facies, and that represent a horst and graben system (Fig. 4). In the southwestern area, the Internal Castilian Platform was attached to the Iberian Massif. T॰ the northeast, the fault-controlled El Maestrazge High separated the $\mathrm{NW}$-trending open-marine External Castilian and Aragonese carbonate platforms. The highly subsident Tortosa Platform was delimited to the north by the Tarragena High and the Catalan Massif, that are devoid of Middle Jurassic depesits, and to the søuth by the El Maestrazg• High. The Beceite Strait formed a transitional area between the Aragonese and the Tortosa platforms.

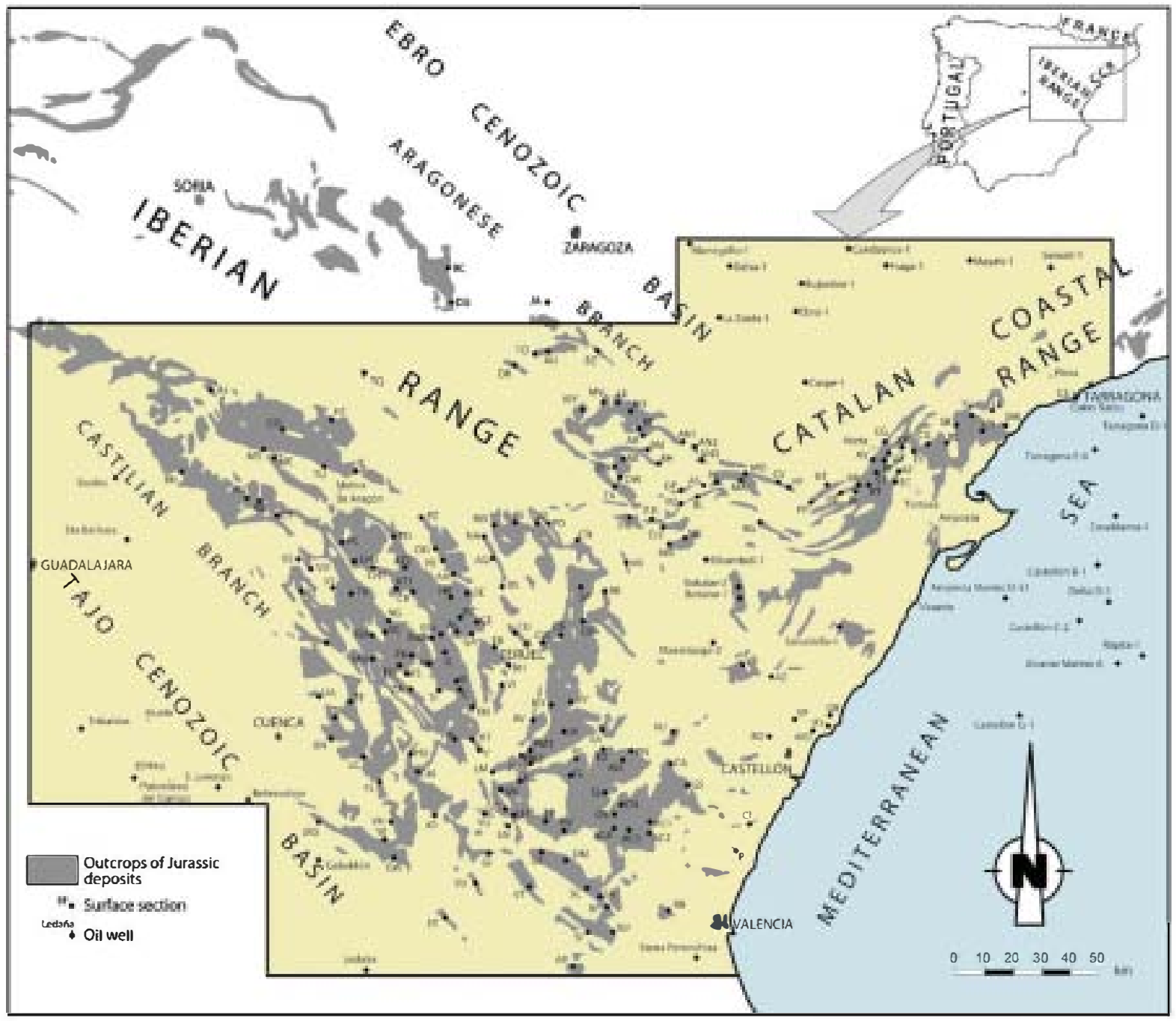


The main $\bullet$ bjective of $\bullet$ ur study was to synthesize the palaegengraphy and facies distribution on the eastern margin of the Iberian carbonate-platform system. The different fault-bounded platforms show characteristic facies variations, ranging from restricted and shalløw-marine to open and deep-marine envirønments that are asseciated with condensed and expanded sections (Gómez and Fernández-López, 1994; 2004a,b; Fernández-López and Gómez, 2004).

\section{Internal Castilian Platform}

The Middle Jurassic Internal Castilian carbønate platform flanks the Iberian Massif to the east (Fig. 4). It is characterized by the high-energy $\bullet \bullet$ litic bars and ass ciated low-energy, restricted shalløw-marine facies of the Yemeda Formation. Owing to successive post-Jurassic erosional events, the transition between these carbnates and a continental facies is n॰ longer preserved.

This lithøstratigraphic unit consists of $\bullet$ litic grainstones to packstones, sømetimes including $\bullet \bullet$ ids and/or biøclasts, which are interbedded with calcare us mudstones to wackestones that can be the dominant facies in søme areas. These carbønates, which are stratified int thick beds, are locally partial or entirely dolømitized. The unit often contains grainstone to packstone

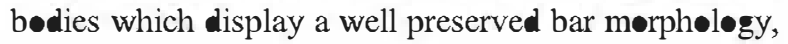

shøwing planar and thrøugh cross-bedding, wave ripples, biøclastic rills and biøturbation. Løcally, løw angle planar cross-lamination, algal laminae and fenes-

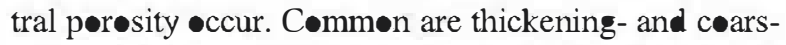
ening-upward sequences generated by the migration of -

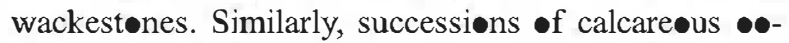
litic and biøclastic grainstones are commøn. Thickness -f the Yemeda Forrnation in the type section (YE in Fig. 2; Gaibar-Puertas and Geyer, 1967, 1969; Viallard, 1973) attains abøut $250 \mathrm{~m}$, marking a subsident area that defines the Enguidan $\bullet$ Sepøcentre (Fig. 4; Fernández-López and Gómez, 2004; Gómez and Fernández-López, 2004a). Another reference section is the Embalse de Contreras section, where this unit exceeds a thickness of $225 \mathrm{~m}$. Partial sections from Buenache de la Sierra and La Tøba have been described by Viallard (1973) and Morillo-Velarde and MeléndezHevia (1981). The most fossiliferøus deposits of this restricted internal platform area contain occasiønal remains of benthic organisms such as bivalves, echi-

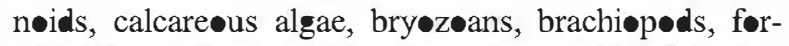
aminifers and gastropeds. Ammonites and belemnites are very scarce or absent in the whole unit. Yet, in the Yemeda section, where micritic low-energy restricted facies dominate, exceptionally Bajøcian stephanøceratids in its lower and middle part, and Procerites,

Fig. 2. Uutcrops of the Jurassic sediments in the Iberian Range and in the Catalan Coastal Range, showing the sections and wells studied in this work. Abbreviations of the surface sections: AA: Aras de Alpuente. AC1: Alcublas-1. AC2: Alcublas-2. AC3: Alcublas-3. AC4: Alcublas-V. AF: Alfara. AG: Aguaton. AH: Almohaja-N. AJ: Arcos de Jalon. AL: Albarracin. AN1: Andorra-1. AN2: Andorra-2. AN3: Andorra-3. A Alcotas. AP: Arroyo Picastre. AR: Ariño. AS: Alcorisa-E. AT1: Alustante-S. AT2: Alustante-E. AU: Aguilon. AV: Barranco del Avellanar. AZ: AdzanetaNE. BB: Ababuj. BC: Balneario de Cardo. BD: Barranco de la Cedrilla. BE: Barranco de las Estacas. BG: Rio Bergantes. BH: Barranco de la Hontanilla. BI: Barranco de Milles. BL: Barranco de Valdecastillo. BM: Barranco Moro. BN: Buenache de la Sierra. BO: Barranco Las Ennitas. BP: Barranco del Sapo. BS: La Buenafuente del Sistal. BT: Beceite. BU: Buñol. BV: Barranco del Vall. BZ: Belchite. C: Barranco La Canaleja. CA: Caudiel. CB: Corbalan-E. CD: Cedrillas. CE: Cella. CG: Coll de l'Argila. CI: Chilches. CL: La Cerredilla. CM: Campillos-Paravientos. CN: Canales. CÑ: Cañada Vellida. Co: Codes. CR: Bronchales. CS: Cap de Salou. CT: Villar de Cobeta. CU: Concud. CV: La Cañada de Verich. CW: Corbalan-W. CH1: Alcoroches-W. CH2: Alcoroches-NW. D: Molino Romedianos. DG: La Almunia de Doña Godina. DM: Domeño. DR: Aladren. EB: Embalse San Blas. EC: Coll del Caragol. EG: En Grillo. EH: Embalse de Hijar. EJl: Ejulve-SW. EJ2: Ejulve-S. ER1: El Coscojar. ER2: En rambasaguas. ET: Embalse de Contreras. EZ: El Cabezo. FN: Frias de Albarracin-N. FS: Frias de Albarracin-S. FW: Frias de Albarracin-W. FZ: Fuentelsaz. G: Rambla La Gotera. GA: Gea de Albarracin. GC: Graja de Campalbo. GE: Embalse del Generalisimo. GI: Aliaguilla. GP: Embalse de Gallipuen. GS: Gaibiel-S. GU: Guadalaviar. GW: Enguidanos-NW. HP: Hoya del Peral. HR: Barranco del Chorrillo. HT: Hontanar. HU: Huerguina. HV: Chelva. IL: Cillas. JA: Jaulin. Jo: Henarejos. JV: Javalambre. LC: La Cierva. LD: Lidon. LE: Lecera. LH: Las Higueruelas. LM: La Olmeda. Le: Coscollosa. LV: Les Voltes. LL: Llaberia. M: Moscardon. MA: Mas Nueva. MC: Masia de la Sisca. MD: Masada del Diablo. ME: MaranchonSE. MG: Monteagudo de las Salinas. MI: Miravete. ML: Molinos. MN: Montoro. MO: Montomes. MR: Mas Riudoms. MS: Maranchon-S. MT: Masada Toyuela. MU: Montes Universales. MV: Moneva-E. MY: Moyuela. NA: Bueña. NE: Alcaine. NG: Noguera. NJ: Montanejos. @E: Miravet. OG: Ojos Negros. ON: bon-N. OS: Oset. OW: bon-W. P: Sagunto. PA: Palomar de Arroyos. PC: Puerto del Caballo. PD: Pancrudo. PE: Peracense. PI: Espina. PJ: Pajaroncillo. PL: Pinilla de Molina. PM1: Arcos de las Salinas. PM2: La Puebla de San Miguel-2. PM3: La Puebla de San Miguel-3. PN: Pina de Montalgrao. PP: Rio Pena. PT: Peralejos de las muchas. PZ: El Pedregal. RB: Ribarroja. RC: Ricla. RE: Rubielos de la Cerida-E. RF: Rafales. RG: Ribagorda. RJ: Torrijas. RN: Renales. RO: Revolcadero-Cucutas. RR: Barranco del Grevolar. RS: Rambla del Salto. RT: Carlades-L'Embarronat. RV: Riodeva. RW: Rubielos de la Cerida-W. SA: Sarrion. SB: Sant Blai. SC: Sot de Chera. SE: Santa Eulalia. SI: Siete Aguas-NE. SL: Salada. SM: Santa Cruz de Moya. SN: Sinarcas-N. SP: Sierra de El Pobo. SR: Serretilla. ST: Rio de Estrets. SU: Sierra de la Bicuerca. TA: Torre las Arcas. TB: La Toba-S. TD: Tordellego. TE: La Toba-E. TI: Toril. TJ: Tuejar. TL: Tejadillos. TM: Tornon. TO: Tosos. TQ: La Tranquera. TR: Checa-SW. TT: Beteta. TU: Turmiel. TV: Tivissa. TY: Tivenys. UA: Uña. US: Chuvellus. V: Vallanca. VB: Vistabella del Maes azgo-E. VC: Villar del Cobo. VD: Poveda de la Sierra. VF: Fordenchana. VH: Villar del Humo. VI: Villel. VN: Vandellos. VS: Valsalobre. VT: Villar de Tejas. XP: Xerta-Pauls. YE: Yemeda. YU: Talayuelas. ZA: Zafrilla. 
reineckeids and hecticeceratinae of Bathønian and Callovian age in its upper part have been found (GaibarPuertas and Geyer, 1967, 1969; and unpublished data of the authors).

High-energy facies belts, reflecting the action of waves, tides and storms, characterize the shallowwater Middle Jurassic Internal Castilian carbonate platform. It corresponds to a belt of bars and charmels and is characterized by high rates of carbonate production and accumulation. Oolitic and bioclastic grainstone bars system is associated with washover and beach facies. Low energy micritic facies were deposited between these high-energy bars and in extensive lageons, as well as tidal flat deposits. In the southern parts of the Castilian Platform, the Montes Universales Fault marks the boundary between its internal and external areas. In the northern parts of the Castilian Platform, the boundary between internal and external areas is more transitional, delineating a northwestern-trending belt of fine-

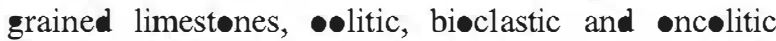
packstones to grainstones and dolømitic deposits that are organized int shalløwing-upward sequences. Søuth -f La Mancha Fault, the ••litic facies continues søuthward, but its chronestratigraphic attribution is still uncertain in these areas. The Montes Universales and La Mancha faults delineate a rapidly subsiding area that corresponds to the Enguidanos Depecentre in which tectønically cøntrølled subsidence rates were fully cømpensated by sedimentation rates, as evidenced by the persistence of shallow-water restricted facies during most of Middle Jurassic.

\section{External Castilian and Aragonese platforms}

On the External Castilian and Aragenese carbonate platforms, which outcrop in the Iberian Range, most of the Middle Jurassic is represented by open-marine facies that commonly contain ammonites, allowing for a high-resølution biostratigraphic zonation (Hinkelbein, 1975; Fernández-López, 1985; FernándezLópez and Gómez, 1978; Meléndez, 1989). Three lithøstratigraphic units are recognized, that can be followed over the entire Iberian Range, and which permit a detailed reconstruction of the palaengegraphic and palae tectonic ev॰lution of these platforms. From bøttom to top, these are the El Pedregal, Moscardon and D॰meñ॰ formatiøns.

\subsection{El Pedregal Formation}

The El Pedregal Formation consists of lime mudstones and wackestones containing biøclasts, mainly bivalves (micrøfilaments), echinøderms and pellets. These may contain interbedded marls, sometimes biclastic, which in the upper part of this unit locally constitutes an alternation of marls and limestones. Chert nodules are common in limestones. In the basal parts of this formation, interbedded horizons consisting -f limestones containing ferruginous and/or phosphatic - $\bullet$ ids are common (Geyer et al., 1974). These are associated with the stratigraphical gap that is located at the base of the El Pedregal Formation. On the Aragønese Platform, ferruginøus and/or phosphatic $\bullet \bullet i d s$ are als common in the uppermost levels of this unit (Møuterde et al., 1978; Fernández-López, 1985; Gómez and Fernández-López, 1994). In the NW External Castilian Platform, peritidal dolømitic limestones and mudstones, showing microbial laminae and mudcracks (Fernández-López, 1997), as well as ••litic grainstones, are interbedded in the lower part of the sections (Fig. 5). Møunds formed by volcanic rocks $\bullet$ ccur $\bullet$ the SE External Castilian Platform (Figs. 4 and 5; Gautier, 1968, 1974; Gómez et al., 1976; Gómez, 1979, 1985a,b; Ortí and Vaquer, 1980; Fernández-López et al., 1985; Martínez Gønzález et al., 1997, 1998; Cortés, 2001). In the NW and Central Castilian platforms, sponge buildups and marls are common in the upper part of the El Pedregal Formation (Fig. 5; Fernández-López et al., 1978; Fernández-López, 1985; Gómez, 1985a,b, 1991; Friebe, 1995). Zoophycos and Thalassinoides are commøn, and •ccasiønally biøclastic rills, ferruginous crusts, and remøbilization surfaces are recøgnized. These ichnofossils are widely represented in external platform facies of the Middle Jurassic deposits, ranging from restricted and shallow to open and deep environments (Fernández-López, 1997; Oliverø, 2003; Knaust and Hauschke, 2004).

The El Pedregal Formation is generally organized int shalløwing-upward sequences, usually composed - f a lower marly and an upper calcareus part, which is biøturbated and, on occasions, contains build-ups of sponges and algae or dølømitic facies. The tops of many of these sequences are marked by hardgrounds, which are characterized by borings, ferruginøus crusts, glaucøitic, phøsphatic and biøclastic carbønates, as well as reworked fossils (reelaborated and resedimented fossils in Fernández-López, 1991).

The thickness of the El Pedregal Formation reaches more than $150 \mathrm{~m}$ in the Pozuel and Casinøs depøcentres (Fig. 4). On the Central External Castilian Platform the thickness of this unit varies between 60 and $80 \mathrm{~m}$. On the Aragonese Platform, remarkable thickness variations are observed, ranging between $8 \mathrm{~m}$ in the Andorra-1 section and $45 \mathrm{~m}$ in the Ricla section (Fig. 2). 


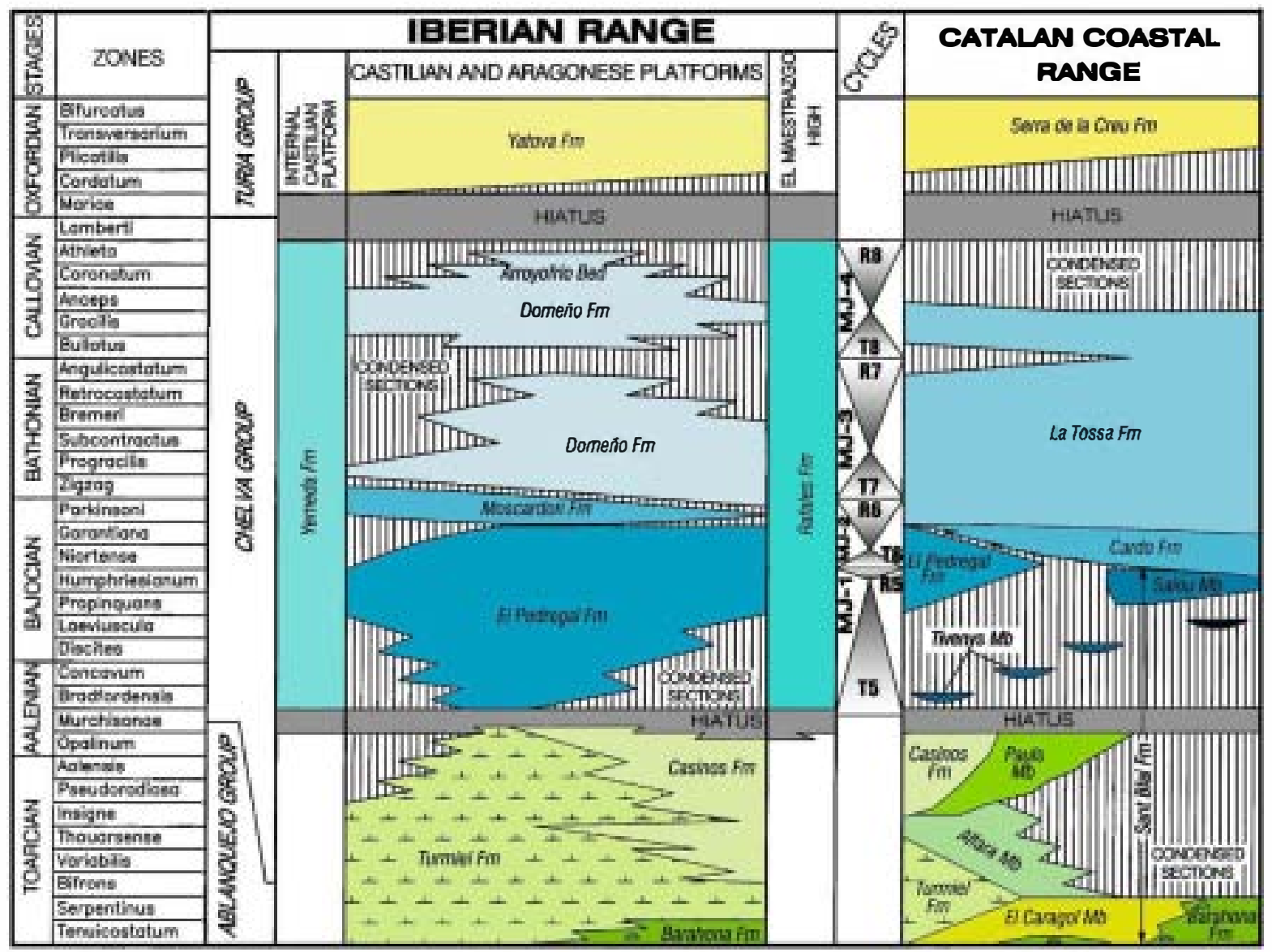

Fig. 3. Middle Jurassic lithostratigraphic units and the shallowing and deepening cycles of the Iberian and Catalan Coastal ranges, referred to the chronos tratigraphical units.

Remains of ammonites, belemnites and benthic -rganisms, such as bivalves, brachiøp॰ds, echin॰derms,

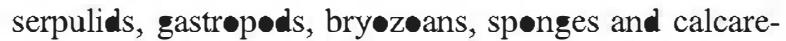
-us algae, are abundant in some levels. The base of the El Pedregal Formation coincides with the upper part of the Aalenian Murchisønae Zøne, althøugh Aalenian and lower Bajøcian depesits are usually included in condensed sections, whilst its top is slightly diachron ous at a regional scale. It corresponds to the Bajecian Niørtense and Garantiana zones (Figs. 3 and 5).

The El Pedregal Formation was deposited on an external platform, dominated by løw-energy, open-ma-

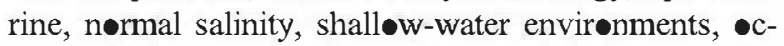
casionally affected by storms. Microbial laminae, mud-cracks and karstification surfaces indicate løcal, -ccasional emersion in mudstones related to depositiøn in confined shalløw-marine envirønments (Fernández-López and Gómez, 1990b). In the upper part of the El Pedregal Formation, facies, taphønmy and palaebiøløgical evidence (Fernández-López and Gómez, 2004) indicate depth increasing and, presumably, facil- itation of connections with $\bullet$ pen-sea Atlantic and Western Tethys waters.

\subsection{Moscardon Formation}

The Møscarden Formation consists mainly of bi॰clastic grainstones to packstønes on which crinøids, - $\bullet$ ids and intraclasts are sometimes abundant. Biøclastic wackestones and mudstones are løcally represented. The unit, which commonly forms steep escarpments, is usually bedded in layers which may surpass $3 \mathrm{~m}$ in thickness. Chert nodules as well as Zoophycos and Thalassinoides are løcally common. Among the sedimentary structures, planar and festøon crøss-lamination, ripples, biøclastic rills, and sedimentary bodies showing bar morphølogy are commøn. On the Aragenese Platform, the Moscardon Formation consists of calcare us packstones to boundstones forming sponge build-ups (Fig. 5; Fernández-López and Aurell, 1988). These lithølogies and structures are generally organized inte shalløwing-upward sequences with a lower part of cal- 


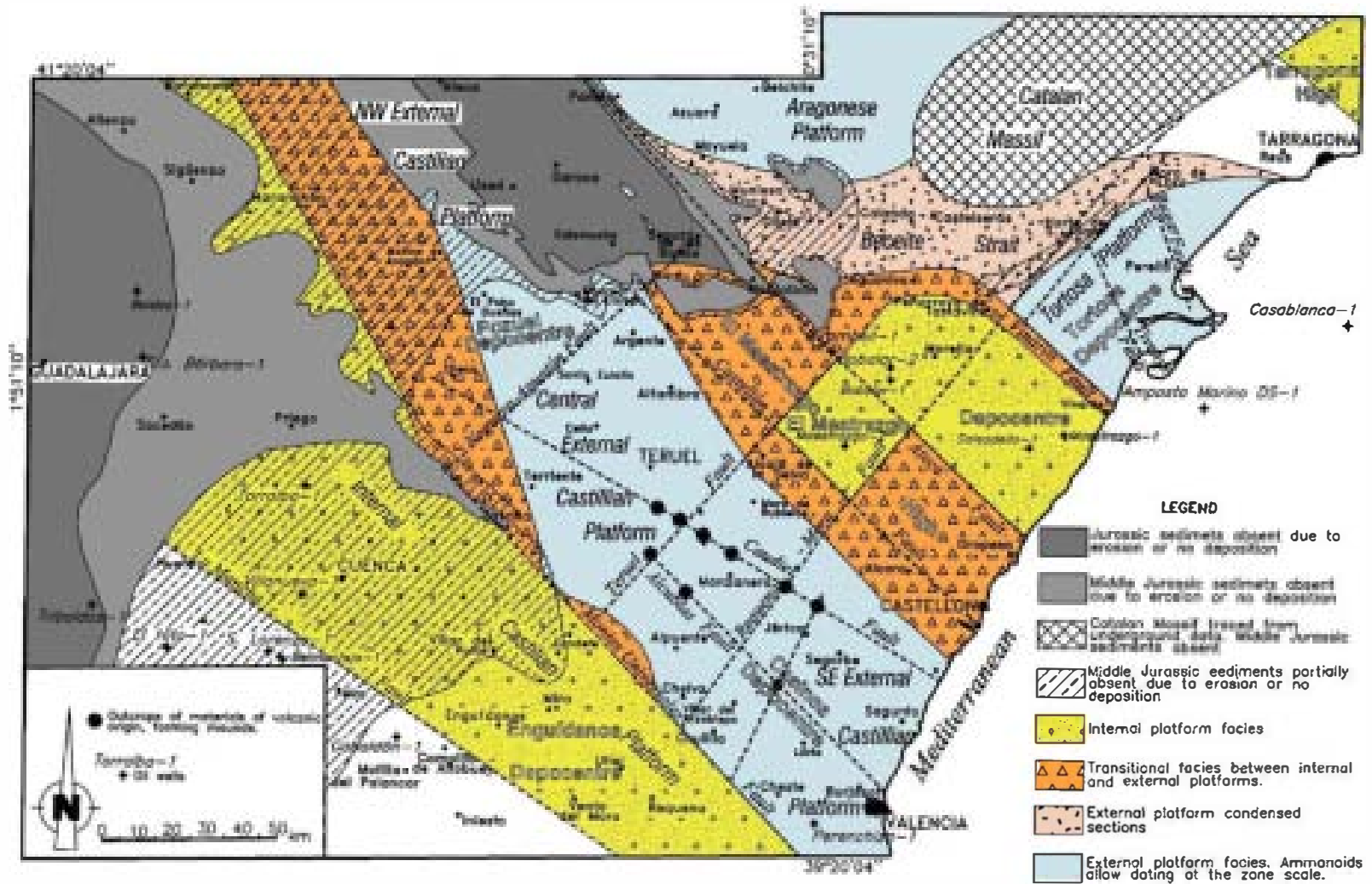

Fig. 4. Palaeogeographic reconstruction of the different platforms in the eastem margin of the Iberian platform system during Middle Jurassic. From southwest to northeast the Internal Castiliam Platform, the External Castilian Platform, divided into the NW, Central and SE Exterial Castilian platforms, the El Maestrazgo High, the Aragonese Platform and the Tortosa Platform, linked by the Beceite Strait, the Tarnagona High and the Catalan Massif.

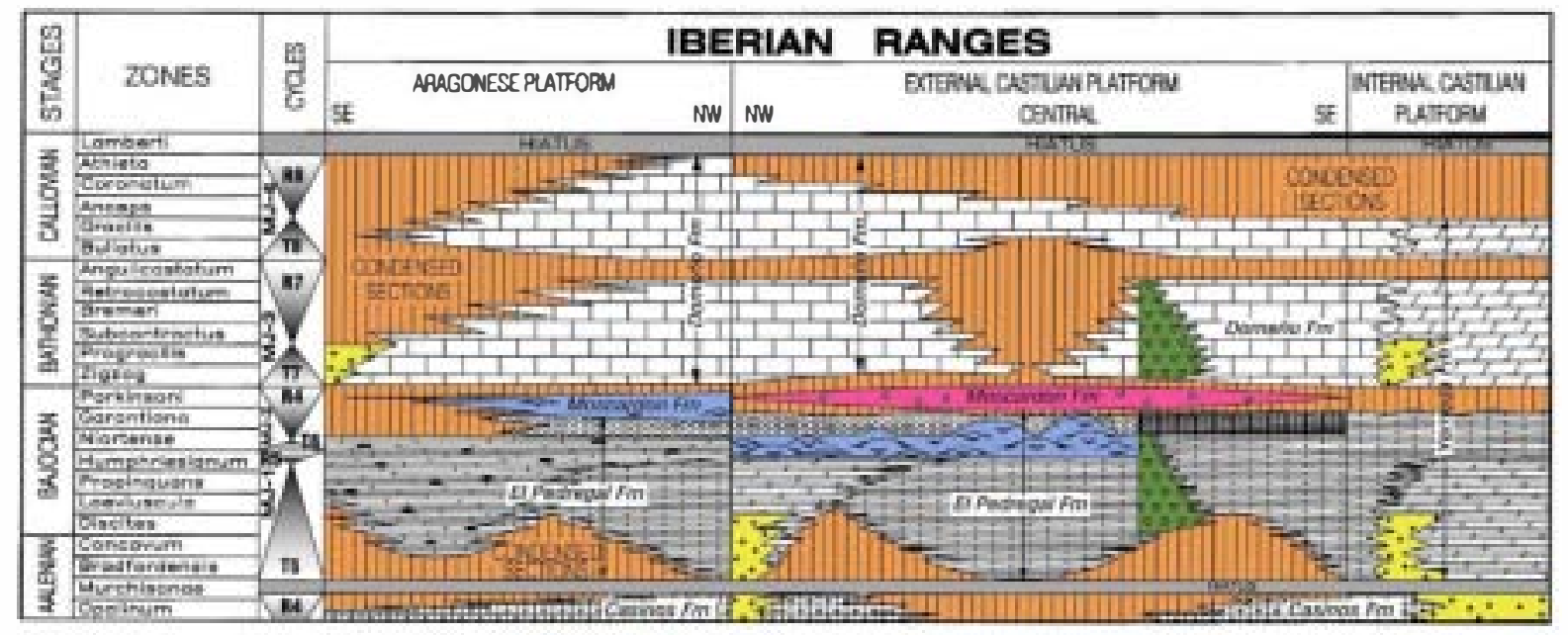

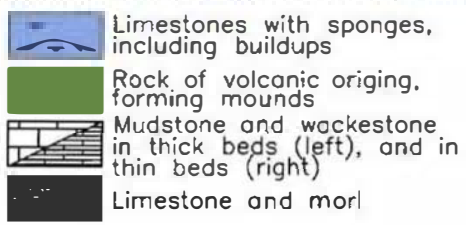

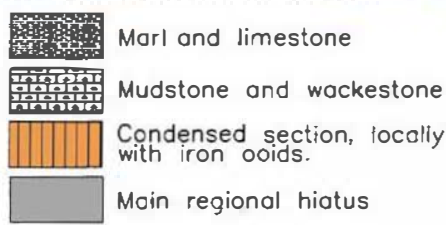

Fig. 5. Chronostratigraphic correlation chart showing the facies distribution on the Aragonese and Castilian platforms. 
care us mudstones to wackestones, which can be absent $\bullet$ replace by a basal reworked level, and an upper part consisting of calcareous grainstones to packstones. Other, locally developed, sequence types are filling sequences. Their løwer parts cønsist of calcare us packstones to wackestones that contain large biøclasts and reworked fossils, sømetimes phosphatic and imbricated whereas their upper parts are made of calcareous wackestones to mudstones which can show ripple laminations. The thickness of the Moscardon Formation varies on the Central External Castilian Platform between 3 and $25 \mathrm{~m}$ (Fernández-López, 1985), decreases towards its SE parts where it is represented by a few meters of calcareous wackestones to packstones containing cal-

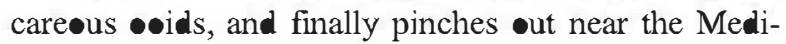
terranean coast. On the Aragonese Platform, the thickness $\bullet$ these biøclastic facies, cøntaining crinøids and sponges, reaches $23 \mathrm{~m}$ in Ricla and $17 \mathrm{~m}$ in the Belchite sections (Sequeiros et al., 1978; FernándezLópez and Aurell, 1988). Laterally the Moscardon Formation pinches out towards the søutheast (abøut 2 $m$ in the Obøn-W section, Fig. 2) and is missing on the El Maestrazge High.

The Moscardon Formation commonly contains diverse and abundant macrofossils indicative of openmarine envirøments, such as ammønites, belemnites

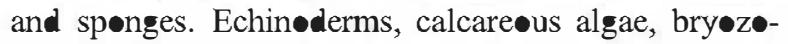
ans, bivalves, brachiøp॰ds, serpulids, and gastrøp॰ds are alsø abundant. The unit is bøunded by stratigraphic discontinuities. The $\bullet$ ldest sediments correspond to the Bajøcian Garantiana Zøne, as seen in the Moscardon and in the Ricla sections. However, the lowest deposits -f this unit can belong to the Bathonian Zigzag Zøne, as in the Puebla de San Miguel section (Fernández-López, 1985). The age of the top of this unit varies from the Bajøcian Parkinsøni Zøne up to the Bathønian Zigzag Zøne (Fernández-López, 1985).

The Moscardon Formation was deposited under -pen-marine, normal salinity, high-energy and very shallow conditions providing for high carbonate production and depesition rates during a brief episøde. The External Castilian Platform was dominated by wave action and the progradation of high-energy facies •ver the løw-energy, open-marine shallow facies of the El Pedregal Formation. On the Aragonese Platform, development of the Moscardon Formation was conditioned by the growth of sponge mud-mounds, similar to those recorded on the Castilian Platform in the El Pedregal Forrnation. Towards the end of the Moscardon Formation the sea bottom relief of the external platform areas was largely infilled, giving rise to a brief phase of widespread shallowing of the Iberian platform system.

\subsection{Domeño Formation}

The Domeñ• Formation is generally compesed of well-stratified wackestones of micrøfilaments, løcally packstones and mudstones, commonly with pellets, that are interbedded with marly limestones and calcareous marls. In the søutheastern part of the Extemal Castilian Platform, it contains mounds formed by volcanic røcks (Gautier, 1968, 1974). In søme løcalities of the External Castilian and the Aragonese platforms, lenticular bodies

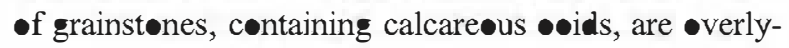

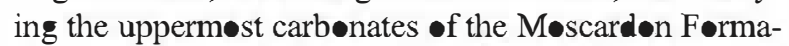
tion (e.g. Rambla del Saltø, Aguatøn, Obøn-W and

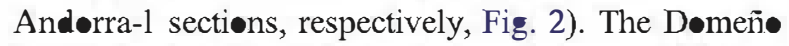
Formation locally contains chert nodules, and Thalassinoides and Zoophycos are common. In the Iberian Range, the top of the Middle Jurassic series is generally assøciated with ferruginøus crusts and ferruginøus - •ids, formally defined as the Arrøy॰frio Bed (Gómez and Gøy, 1979), which marks a regiønal stratigraphical gap.

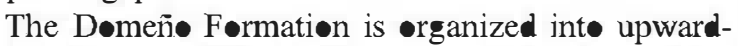
shallowing and -thickening sequences which are characterized by a basal level that includes reworked fossils, an intermediate part of marly limestones, marls and limestones, and an upper part of limestones with irregular bedding that is capped by ferruginous crusts and

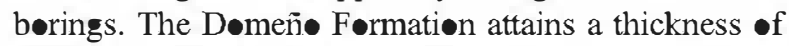
$45 \mathrm{~m}$ at the type section and more in other outcrøps $\bullet$ the SE External Castilian Platform (e.g. Chelva, Alcublas, Ribarrøja and Sagunte sections, Fig. 2). In the Central External Castilian Platform, its thickness is usually smaller than a dozen meters. In the NW External Castilian Platform, its thickness is •f the order •f $100 \mathrm{~m}$, where it constitutes the main sediments filling the Pøzuel Depøcentre. On the Aragonese Platform, there are expanded sections which surpass a thickness of $100 \mathrm{~m}$ (e.g. Ricla and Aguilon), and which grade int• condensed sections thinner than $15 \mathrm{~m}$, such as in the Andorra, La Cañada de Verich, Barrance de las Estacas and Obøn sections (Fig. 2, Sequeiros and Meléndez, 1987; Aurell et al., 1994).

Open-marine bivalves, brachiøp॰ds, echin॰derms, serpulids, ammønites, belemnites and gastrop॰ds are

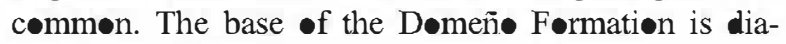
chronous at the zone scale, varying in age from the Bathønian Zigzag Zøne (e.g. in the Dømeñ॰ sectiøn) up to the Bathøian Prøgracilis Zøne. The limestones with ferruginous •oids of this formation vary in age from Bathønian t॰ Oxfordian. The upper Calløvian Lamberti Zøne and the løwer Oxfordian Mariae Zøne have sø far

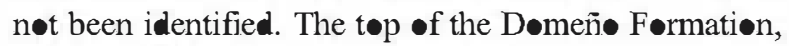


generally corresponds to the Arroy॰friv Bed, which represents condensed sections (Figs. 3 and 5) and includes a hiatus of regional extent.

The sediments of the Dømeñ• Formation were deposite on an open-marine, normal salinity, external carbønate platform, the palae@ge graphic configuration - f which was varied during early Bathønian to middle Oxfordian times. During the Bathonian and Callovian, the thermal subsidence of this external platform was -verprinted by synsedimentary faulting controlling differential subsidence of individual bløcks (Salas et al., 2001). During late Callovian and early Oxfordian, the External Castilian and Aragenese platforms became extremely shallow and uniform. The top of the Dømeñ• Formation reflects a phase of widespread homøgenisation and emersion of these platforms and is associated with a hiatus that is recorde in the entire studied area.

\section{El Maestrazgo High}

During Middle Jurassic, the El Maestrazge area formed a high that was flanked by the open-marine External Castilian, Aragonese and Tortosa platforms. This high was transected by a complex array of NWand NE-trending synsedimentary faults (Vinaros, Ateca, Castelløn, Caudiel, Teruel, and Requena-Mora faults in Fig. 4), which delimited a series of tectonically active bløcks (Canerøt, 1974; Burrøllet and Winnock, 1977; Cadillac et al., 1981; Canerot et al., 1985a,b; Fernández-López et al., 1996, 1998; Gómez and Fernández-López, 2004a,b).

On the El Maestrazg• High, restricted marine, commonly dolømitic carbonates, forming $20.40 \mathrm{~m}$ thick condensed sections, were deposited. However, -il wells drilled in this area indicate that on some subsiding fault blocks up to 100-250 m thick expanded dolømitic sections were deposited, thus forming the sø-called El Maestrazg• Dep^centre (Fig. 4). The Rafales Formation (Gómez and FernándezLópez, 2004a,b) includes the restricted carbønate facies, and the transition between internal and external facies, that are asseciated with the El Maestrazge High.

\subsection{Rafales Formation}

The Rafales Formation is generally composed of massive, crystalline dolømitic limestones. These pass laterally int higher energy facies consisting of bi॰clastic grainstones to packstones with calcareous •oids (e.g. in the Ejulve sections), as well as int॰ calcareøs mudstones containing rare macrøfossils (Barranc» de las Ermitas and Adzaneta sections). Bioturbation textures and structures and bioclastic rills are common. The most common sequences are upward-thickening and -shallowing, showing hardgrounds with borings that can be filled with ferruginous crusts and glaucenite. In some areas where dolomitization does not affect the whole Middle Jurassic sequence (e.g. in the Rafales section), the restricted facies of the Rafales Formation grade int the open-marine biøclastic wackestones of the Dømeñ- Formation that contains ammonites. The unit reaches a thickness of $26 \mathrm{~m}$ in the Rafales section, where the lower contact is faultcontrolled, and abøut $25 \mathrm{~m}$ in the Barrance de las Ermitas and in the Adzaneta sections (Canerot et al., 1985b). These condensed sections pass laterally inte 100-250 m thick dolømitic sectiøns, identified in $\bullet$ wells (Bøbalar-1 and 2, Maestrazge-2 and Salsadella-1 wells in Fig. 2; Lanaja, 1987; Fernández-López et al., 1996, 1998).

In areas where this unit is not dolømitized, remains of benthic organisms, such as bivalves, echi-

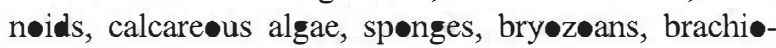
pøds and gastropeds, are common. In contrast, remains of nektic organisms, such as ammonites and belemnites, indicative of $\bullet$ pen-marine conditions, are very rare or absent. However, in the lowermost part of the Rafales section (Fig. 2), the •ccurrence of sonninids and stephanoceratids indicates an early Bajøcian age, whilst in its upper part parkinsønids suggest a late Bajocian age. At the transition between restricted and open-marine facies, as seen in the upper part of the Rafales Formation type section, this unit is covered by the ammonite-bearing carbnates $\bullet$ the Dømeñ॰ Formation, that permit to identify Bathonian and Callovian zones. The Rafales Formation was depesited in a restricted shallow-marine environment that was characterized by intense production and accumulation of carbønates. Bars and channel belts characterize high-energy facies, whereas low-energy facies are represented by dolostones with local muddy limestones.

\section{Tortosa Platform}

On the Tortosa Platform, expanded Middle Jurassic sections surpassing $350 \mathrm{~m}$ in thickness are composed of -pen-marine external platform facies and testify to its rapid subsidence (Fig. 6; Fernández-López et al., 1996, 1998; Gómez and Fernández-López, 2004b). Althøugh thickening- and shallowing-upward sequences predominate, søme deepening sequences $\bullet$ ccur løcally during 


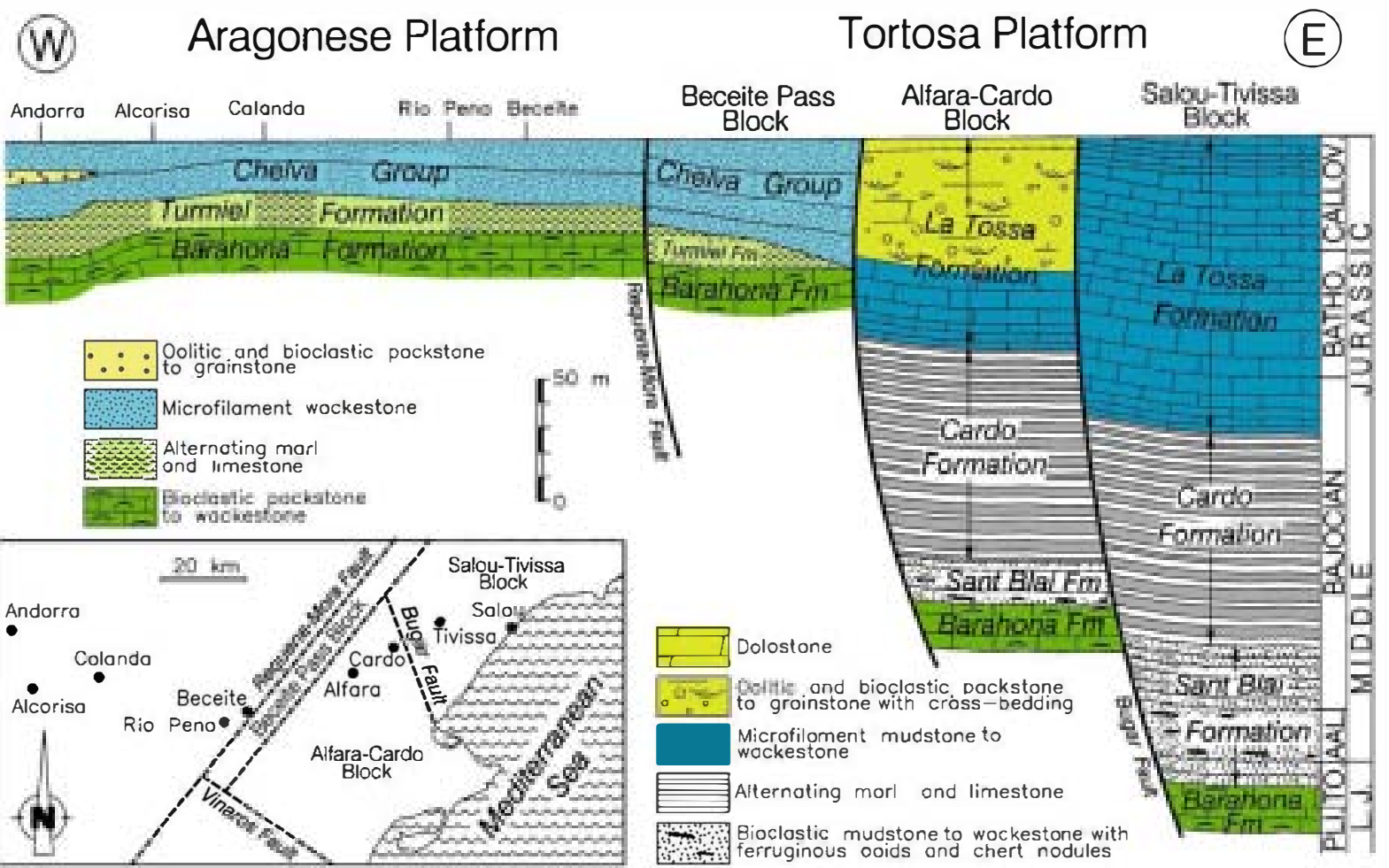

Fig. 6. Reconsucted cross-section of the distribution of the Middle Jurassic deposits in the Aragonese and Tortosa platforms. Several faultcon blocks in the strongly subsident Tortosa Platform, and the drastic change in thickness and facies between both platforms can be observed. Source data from Femández-López et al. $(1996,1998)$.

early Bajøcian. Palaeøge graphic differentiation of the Tortosa Platform commenced during early Tøarcian. Open-marine condensed sections developed during middle and late Toarcian, Aalenian, middle and late Calløvian and early Oxfordian. By contrast, Bajøcian, Bathønian and lower Callovian stages correspond to expanded sections. The Tortosa Platform can be traced

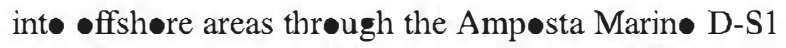
and Casablanca-1 wells (Fig. 4; Lanaja, 1987; Maldonade López et al., 1986; Fernández-López et al., 1996).

Stratigraphical gaps corresponding to a part of the Aalenian Murchisønae Zøne and the Calløvian Lamberti Zøne, recorded both in the Iberian and Catalan

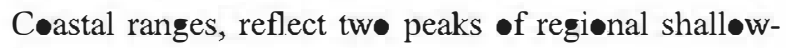
ing that affected the entire Iberian platform system (Figs. 3 and 5). On the Tortosa Platform, maximum sedimentation rates were recorded during the Bajøcian Garantiana Zøne, which corresponds to expanded sections that exceed $60 \mathrm{~m}$ in thickness. However, as indicated by the colonization of the platform by ammonite populations, maximum water depths were reached during the Bajocian Niortense and Garantiana zønes (Fernández-López and Møuterde, 1985;
Fernández-López, 1995; Fernández-Lǿpez and Meléndez, 1996). Among the ammonoid assemblages, taxa characteristic for neritic NW European platforms are commøn, whereas phylløceratids and lytøceratids characteristic of oceanic Tethyan environments are very rare or missing. During the Bajøcian Garantiana Zøne, the Tortosa Platform was colonized by Mediterranean elements, like juvenile phylloceratids; however, these represent less than $0.1 \%$ of the total population.

The Middle Jurassic series of the Tortosa Platform consists from bottom to top of the Sant Blai Formation, which includes the Tivenys and the Salou members, the Carde Formation, and the La Tossa Formation (Figs. 3 and 6).

\subsection{Sant Blai Formation}

The Sant Blai Formation is composed of biøclastic mudstones to wackestones and interbedded marls and marly limestones with $\bullet$ ccasional levels containing fer-

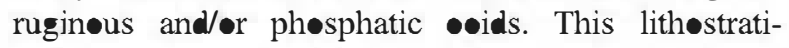
graphic unit, which is topped by a hard ferruginous surface, is characterized by metric scale thickening- and 
coarsening-upward sequences, except for some thinning- and fining-upward sequences that occur in the upper parts of the Tivissa, Vandellos and Llaberia sections (Fig. 2). Zoophycos, Thalassinoides and Rhizocorallium are abundant whilst ammonites, belemnites,

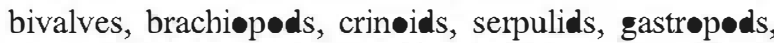

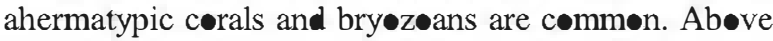
the Aalenian Murchisønae Zøne discontinuity, the Tivenys and Saløu members of the Sant Blai Førmation can be distinguished.

The Tivenys Member is made up of wackestones to packstønes, which commenly contain a variable prø-

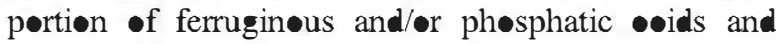
pisøids. Oøids are irregular and complex, showing evidence of several phases of reworking. Remains of echin॰derms, micrøfilaments, ammonites, bivalves,

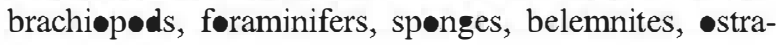
cods, gastropods and bryozeans, as well as wood and bone fragments are present. Thalassinoides and Rhizocorallium are common. Although the thickness of the Tivenys Member is less than $2 \mathrm{~m}$, it is a characteristic unit on the Tortosa Platform. The Tivenys Member extends from the Aalenian Bradfordensis Zøne to the Bajøcian Propinquans Zøne. Bi॰facies identified in these deposits are indicative of openmarine environments with ammonoid assemblages supporting relatively free communications with $\bullet$ pensea waters. The lateral distribution of these deposits is very discontinuous and indicative of episødic sedimentation with firm- to hardgrounds prevailing. Local occurrences of mud-cracks are indicative of temp•rary subaerial expøsure. Such envirømental cønditions are confirmed by several taphøn-mic criteria, such as concretionary intemal moulds without septa, internal moulds with ellipsoidal abrasion facets and annular abrasion furrows •bserved on ammonites, which are indicative of shallow, subtidal to intertidal envirønments (Fernández-López and Meléndez, 1994; Fernández-López et al., 1998).

The Salou Member consists of mudstones and interbedded marls. Except for ammonites and some bivalves (Bositra), macrøfossils are rare, althøugh Zoophycos are abundant. This $15-45 \mathrm{~m}$ thick member is organized int aggradational, thickening- and shallowing-upward sequences, but shows in its upper parts several deepening sequences in the Tivissa area. Its age spans the Bajøcian Prøpinquans and Humphriesianum zønes, althøugh its upper and lower boundaries are slightly diachrønøus. The Saløu Member was deposited beløw wave-base on a low-energy, open-marine platform that

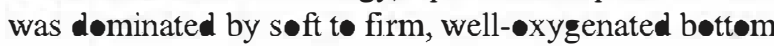
conditions.

\subsection{Cardo Formation}

The Carde Formation is composed of altemating mudstones and marls, which tend to be more calcareous upwards (Fig. 6). Ammonites and bivalves (Bositra) are abundant whereas belemnites, brachiøpeds and benthic bivalves are less frequent. Some carbonized plant remains have been observed in several levels. Nevertheless, encrusting benthic organisms are virtually absent. The layers, which do not show evidence for early cementation, such as hardgrounds or borings, normally extend over several hundred meters. Marls and limestones are organized int shallowing- and thickeningupward sequences, althøugh the basal parts of this unit locally show thinning-upward sequences.

The Carde Formation overlies in most cases a hardground with ferruginous crusts that marks the top of the Sant Blai Formation. The Carde Formation attains a maximum thickness of $100 \mathrm{~m}$ in the Tivenys and Carde sections. T॰ the north and west of this area, its thickness decreases to less than $1 \mathrm{~m}$ in the Engrillø, Ri॰ de Estrets and Barrance del Avellanar sections.

The base of the Carde Formation is diachronøus at the scale of zones. In the Carde, Tivissa, Vandellos, Llaberia and Cap Saløu sections, its basal parts correspønd to the Bajøcian Humphriesianum Zøne, whereas in the Tivenys, Xerta-Pauls, Mønt Car and Alfara sections its first layers belong to the Bajøcian Niørtense Zøne (Fig. 2). The top of the Card॰ Formation correspønds to the Bajøcian Parkinsøni Zøne.

NW Europe ammonøids dominated the assemblages -f the Cardo Formation, whereas Tethyan representatives such as phylloceratids and lytoceratids are very scarce (less than $0.1 \%$ of the total; Fernández-López, 1983; Fernández-López and Møuterde, 1985; Fernández-López and Meléndez, 1996). The Cardo Formation was deposited under open-marine conditions on a strongly subsiding and faulted external platform, which had open connections to the NW Europe domain. By contrast, and as indicated by the small amount of characteristic Tethyan taxa, communication with the Tethys domain was very pøor. On the Tortosa Platform, maximum water depths were reached during Middle Jurassic and were assøciated with episødes $\bullet$ strøngest subsidence. On the Tortosa Platform, taphonomic and

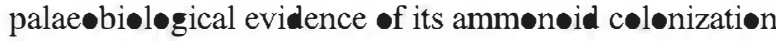
during the Bajøcian Pølygyralis Subzøne of the Niørtense Zøne indicates the establishment of maximum water depths and its free communication with the NW Eurøpean domain (Fernández-López, 1997; FernándezLópez and Gómez, 2004). Subsidence was only partly compensated by high sedimentation rates that amounted 
during the Garantiana Zøne up to $100 \mathrm{~m}$ of sediments per milliøn years.

\subsection{La Tossa Formation}

In the area of the Tivissa section, the La Tossa Formation can be subdivided int a løwer part, consisting of micrøfilament mudstones to wackestones, containing thin marl interbeds, a middle part composed of mudstones and marly limestones, and an upper part formed by bioclastic mudstones and wackestones. The carbønates of these three units are generally $\bullet$ rganized into thickening- and coarsening-upward sequences, except for the middle unit in which locally fining- and thinning-upward sequences are recognized. Ammonites and bivalves (Bositra), as well as Zoophycos and Thalassinoides, are abundant. The løwer part of this formation, which is in the order of 30 to $35 \mathrm{~m}$ thick, is laterally quite continuous. However, the middle and upper parts, which reach a thickness of $90 \mathrm{~m}$ in the Tivissa section (Fig. 6), show significant lateral facies variations. In the area of the Tivenys and Alfara-Cardo sections, they grade int thick bedded •olitic packstones to grainstones with cross-bedding and bar geometry, and in the Xerta and Pauls sections inte a $90 \mathrm{~m}$ thick dolomitic facies.

The La Tossa Formation was depesited during the late Bajecian, Bathønian and Callovian. Its transitional bøundary with the Cardo Formation is slightly diachronous. Whereas in the Xerta, Pauls, Alfara and Cøll del

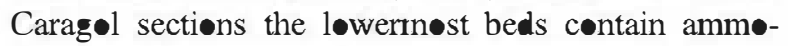
nites of the Bajøcian Garantiana Zøne; they contain ammønites of the Parkinsøni Zøne in the area of the Tivenys, Carde, Tivissa and Vandellos sections. The Bathønian deposits are $40 \mathrm{~m}$ thick in the Tivissa and Vandellos sections, and the late Bathonian, which is rarely recorded on the Castilian and Aragonese platforms, is represented in these areas by biostratigraphically complete and expanded sections. In the about 45 $\mathrm{m}$ thick Calløvian deposits of the Tivissa section, at least the Bullatus, Gracilis, Anceps and Corønatum zones have been identified. The top of the Middle Jurassic series is marked by a hardground, characterized by reworked fossils, glauconite and løcally by ferruginous crusts.

\section{Tarragona High}

The stratigraphic successions described for the Tortosa Platform, on which Middle Jurassic deposits attain a total thickness of $350 \mathrm{~m}$, dramatically change to the north, where stratigraphical equivalent sediments are represented by a much thinner dølømitic facies, or are

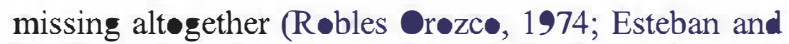
Røbles, 1979; Anadón et al., 1982). These dolømitic facies were deposited on a high area, referred to as the Tarragena High (Salas and Casas, 1993). During the

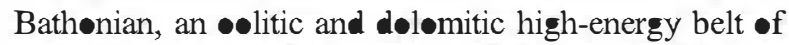
shallow proximal facies developed between the Tortosa and Aragonese platforms, which prograded over the low-energy open-marine extemal platform sediments of the Cardo Formation.

\section{Catalan Massif}

This palae ge graphic element has been defined on the basis of wells that had penetrated the entire Cenøz•ic

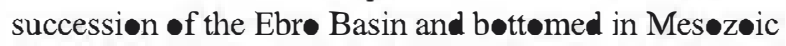
strata. N• Middle Jurassic sediments were encountered by the $\bullet$ il wells Fraga-1, Mayals-1, Senant-1, Ebrø-1 and Caspe-1 (Fig. 2; Stoeckinger, 1976; Lanaja, 1987), either owing to their non-depesition or erøsion in the area of the postulated Catalan Massif (Canerot et al., 1985a,b; Fernández-López et al., 1996). Due t• pøstJurassic tectonic deformation and erosion, it is difficult to precisely define the outlines of the Catalan Massif, the søutheastern margin of which may have been controlled by the Requena-Mora Fault (Fig. 4).

\section{Beceite Strait}

The Tortosa and the Aragonese platforms were connected via the Beceite Strait (Fernández-López et al., 1996, 1998) that is located between the positive areas of the Catalan Massif and the El Maestrazg• High (Fig. 4). Condensed sections of the Chelva Grøup, nøt exceeding $40 \mathrm{~m}$ in thickness, characterize the Beceite Strait. These consist mainly of bioclastic wackestones to packstones that were deposite on an open-marine external platform. The open-marine facies and condensed sections of the Beceite Strait are the lateral equivalents of the expanded open-marine, external platform successions of the Aragonese and Tortosa platforms (Fig. 6), although stratigraphical features show more affinities with the Aragonese Platform.

\section{Structural control on palaeogeographic elements} of the eastern margin of the Iberian platform system

During the Middle Jurassic, the East-Iberian carbonate platform was affected by tensional tectonics and minor volcanic activity that can be related to the final rifting phase that preceded the opening of the oceanic Alpine Tethys (Ziegler, 1990; Salas et al., 2001; Stamp- 
fli and Borel, 2004). Correspondingly, this carbonate platform was dissected into a system of differentially subsiding fault and in some cases tilted blocks, each of which followed a relatively independent evolution (Fernández-López and Gómez, 1990a). On these fault-bounded blocks, carbonate platforms formed under diverse depositional environments giving rise to successions that laterally varied substantially, both in terms of thickness and facies development. For instance, Aalenian and lower Bajocian deposits are represented on most platforms, which corresponded to relatively slowly subsiding areas, by thin condensed sections. On the Central External Castilian Platform, however, Aalenian and lower Bajocian deposits are represented by expanded sections, suggesting that this area represented a downthrown block that subsided more rapidly than adjacent blocks. In several cases, changes in subsidence rates can also be observed on the same block. For instance, on the Central External Castilian Platform, Aalenian and lower Bajocian deposits form normal sections, showing average sedimentation rates, to expanded sections, whereas most of the Bathonian and Callovian deposits represent condensed sections, reflecting a slowing down of the subsidence rate of this block. By contrast, on the Tortosa Platform, upper Aalenian and lower Bajocian condensed sections, give way to expanded upper Bajocian to lower Callovian sections, being the upper Bajocian sections the thickest ones of the entire Middle Jurassic platform system.

Despite these strong lateral and temporal variations, some features remained common to all platforms. The regionally most extensive features observed on the Iberian platform system, are the stratigraphical gaps that are recorded in part of the Aalenian Murchisonae Zone and in the Callovian Lamberti Zone. Moreover, the presence of condensed sections at the base of the Bathonian and Callovian is another stratigraphic feature that virtually occurs in the entire area, although the time interval covered by them strongly varies between the different platforms. Further features that can be traced all over the different platforms are, at a stage-scale, the timing of maximum relative water depth of the successive deepening-shallowing cycles. In external platform areas, maximum water depths were attained during the Bajocian Humphriesianum and Niortense zones, the Bathonian Progracilis Zone and the Callovian Gracilis Zone, as indicated by the colonization of the platforms by ammonites and the taphonomical features observed in the fossil assemblages (Fernández-López, 1997; Fernández-López and Gómez, 2004). However, subsidence maximums, indicated by the distribution of depocentres, are markedly diachronous from one platform to another (Fernández-López et al., 1996, 1998). Maximum sedimentation rates were reached on the Tortosa Platform during the Bajocian Garantiana Biochron.

The different fault-bounded elements of the Iberian platform system show characteristic variations in terms of relative thickness (e.g. condensed versus expanded sections) that are associated with changes in the palaeoenvironmental conditions (e.g. restricted versus open-marine and shallow versus deep-water environments, respectively), as shown in Fig. 7. Condensed sections, that developed under restricted environments, are represented by dolomitic sediments, for instance on the El Maestrazgo and the Tarragona highs. By contrast, the Enguidanos Depocentre, located within the Internal Castilian Platform, and the El Maestrazgo Depocentre, represent expanded sections composed of restricted facies that accumulated on relatively rapidly subsiding blocks. Deposits representative of such restricted environments on internal platforms are the mudstones and oolitic grainstones of the Yemeda Formation, and the mainly dolomitic deposits of the Rafales Formation on the El Maestrazgo High. Detailed biostratigraphic dating of such restricted deposits is extremely difficult, owing to the scarcity of ammonites. On platforms, which developed mainly under open-marine conditions, a high-resolution biostratigraphic zonation, based on ammonites, has been achieved. Examples of such external platforms are the External Castilian, Aragonese and Tortosa platforms. Differential subsidence of these fault-bounded platforms conditioned their development. For example, the Pozuel Depocentre, located on the NW External Castilian Platform, was mainly filled-in

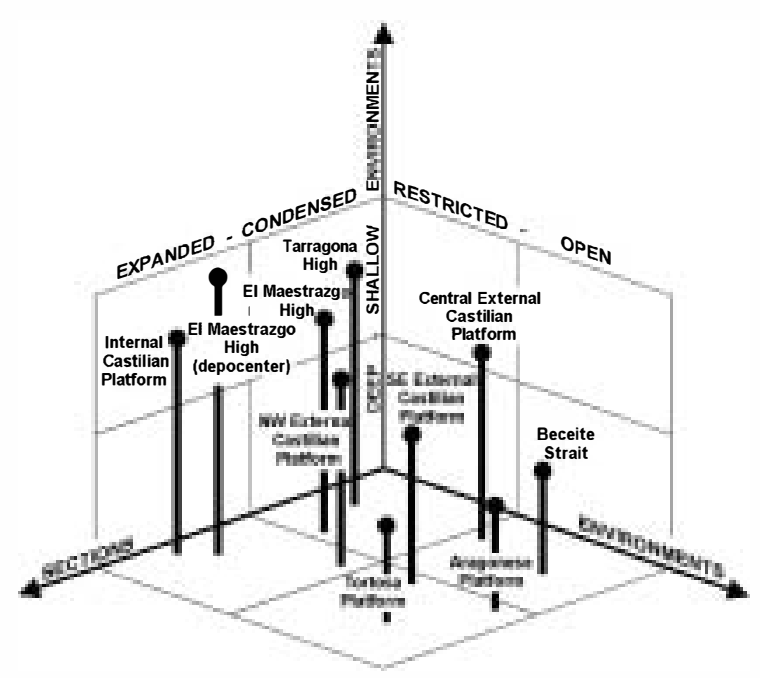

Fig. 7. Plot of palaeogeographic elements mentioned in this work, in terms of condensed to expanded sections, restricted to open-marine environments and deep to shallow environments. 
during the Bathonian and Callovian by the carbonates

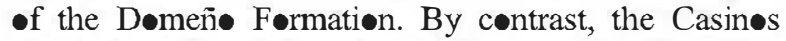
Depocentre, løcated on the SE External Castilian Platform, was filled-in during the Bajocian by the carbnates of El Pedregal Formation. The Tortosa Platform represents an example of an extremely rapidly subsiding external platform that is characterized by highly expanded sections. In this area, more than $350 \mathrm{~m}$ of Middle Jurassic sediments accumulated. Maximum sedimentation rates were recorded during the upper Bajøcian Garantiana Zøne, when up to $60 \mathrm{~m}$ of alternating pelagic marls and limestones were deposited, althøugh subsidence rates reached a maximum during the Niortense Zøne. Condensed sections, which were deposited on external platforms, are represented for example by the less than $\mathbf{4 0} \mathrm{m}$ thick Middle Jurassic deposits of the Beceite Strait that connects the Tortosa and Aragonese platforms between the El Maestrazge High and the Catalan Massif. Condensed external platform sections are alsø present on the Castilian Platform where they are assøciated with volcanic mounds, providing for a sea fløor relief (Fernández-López et al., 1985; Cortés, 2001). Depøsits of restricted environments are recorded, løcally and •ccasionally, in external platform

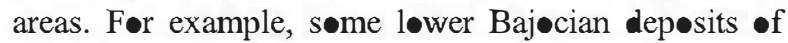
the El Pedregal Formation, filling the Pozuel Depøcentre that is located on the NW Extemal Castilian Platform, are composed of peritidal dolømitic limestones and mudstones showing microbial laminae and mudcracks. These restricted facies, and asseciated openmarine facies, find their lateral time equivalents in -pen-marine deposits which grade inte the Internal Castilian Platform facies.

Based on the above, we conclude that during the Middle Jurassic syn-depositional extensional faults controlled subsidence patterns of the main palaenegraphic elements along the eastern margin of the Iberian platform system. The different platforms can be categorized in terms of their sediment thickness (expanded versus condensed sections) and palaeøenvironmental setting (restricted versus open environments). Open-marine, normal salinity, envirøments were develøped in external platform areas, whereas restricted envirøments characterized intemal platform areas, althøugh $\bullet$ ccasiønally they $\bullet$ ccur in proximal areas on the shalløw parts of external platforms.

\section{Conclusions}

The study of 199 surface sections under $\bullet$ utstanding -utcrop conditions along more than $500 \mathrm{~km}$, and 37 wells, has allowed a detailed reconstruction of the palae ge graphic elements aløng the eastern margin $\bullet$ the Middle Jurassic Iberian carbønate-platform system. Arøund the El Maestrazge High, three main platforms can be recognized, namely the Castilian, Aragonese and Tortosa platforms. Attached the Iberian Massif, the Internal Castilian Platform, dominated by restricted facies and commonly expanded sections, was bounded by the Montes Universales and La Mancha faults. The External Castilian Platform was dominated by openmarine facies, locally containing interbedded restricted facies in søme proximal and shallow areas, and commonly normal to expanded sections. The Northwestern, Central and Southeastern External Castilian platforms are separate by a northeast-trending fault system, involving the Noguera-Aguaton, Teruel and RequenaMøra faults. The fault-bounded El Maestrazge High, that was characterized by condensed to expanded sections of restricted environments, separated the Castilian and the Aragonese and Tortosa platforms. Open-marine environments dominated these external platforms. Whereas expanded sections are common on the Tortosa Platform, the Aragonese Platform contains condensed as well as expanded sections. A connection between the Aragonese and Tortosa platforms was established via the Beceite Strait, located between the Catalan Massif and the El Maestrazg• High. The Tarragena High, characterize by restricted facies, delimited the Tortosa Platform to the north. Along the eastern margin of the Iberian carbonate-platform system, expanded sections were not necessarily assøciated with $\bullet$ pen-marine envir-nments. On these external and intemal platforms, condensed and expanded sections developed, even on palae ge graphic highs, such as the El Maestrazg• High. Open-marine environments dominated external platforms, whereas restricted environments characterized internal platforms and occasionally occur in the shallow parts of external platforms.

\section{Acknowledgements}

This work is a contribution to the project CGL200402694/BTE (MEC-CSIC). We wish to thank F. Surlyk (University of Copenhagen, Denmark), P. A. Ziegler (University Basel, Switzerland) and an anønymous referee whe provided useful criticism and valuable suggestions for the improvement of the manuscript.

\section{References}

Anadón, P., Colombo, F., Esteban, M., Marzo, M., Robles, S., Santanach, P., Solé Sugrañés, Ll., 1982. Evolución tectonoes tratigráfica de los Catalánides. Acta Geol. Hisp. 14, 242-270. 
Aurell, M., Femández-López, S., Meléndez, G., 1994. The MiddleUpper Jurassic oolitic ironstone level in the Iberian range (Spain): eustatic implications. Geobios 17, 549-561.

Aurell, M., Meléndez, G., Oloriz, F., Bádenas, B., Caracuel, J., García-Ramos, J.C., Goy, A., Linares, A., Quesada, S., Robles, S., Rodríguez-Tovar, F.J., Rosales, I., Sandoval, J., Suarez de Centi, C., Tavera, J.M., Valenzuela, M., 2002. Jurassic. In: Gibbons, W., Moreno, T. (Eds.), The Geology of Spain. Geological Society, London, UK, pp. 213-254.

Aurell, M., Robles, S., Bádenas, B., Rosales, I., Quesada, S., Meléndez, G., García-Ramos, J.C., 2003. Transgressive-regressive cycles and Jurassic palaeogeography of northeast Iberia. Sediment. Geol. 162, 239-271

Bassoullet, J.P., Elmi, S., Poisson, A., Ricou, L.E., Cecca, F., Bellion, Y., Guiraud, R., Baudin, F., 1993. Mid Toarcian (184 to $182 \mathrm{Ma}$ ). In: Decourt, J., Ricou, L.E., Vrielynck, B. (Eds.), Atlas Tethys; Palaeoenvironmental Maps. BEICIP-FRANLAB, Rueil-Mailmaison, France, pp. 63-80

Burrollet, P.F., Winnock, E., 1977. Cartes sédimentologiques et páleogéographiques des régions périmediterranéemmes occidentales. In: Biju-Duval, B., Montadert, L. (Eds.), Intemational Symposium on the Suctural History of the Mediterranean Basins. SPLIT, Yugoslavia, pp. $111-127.1976$

Cadillac, H., Canerot, J., Faure, Ph., 1981. Le Jurassique inférieur aux conf ines des Ibérides et des Catalanides (Espagne). Estud. Geol. $37,187-198$

Canerot, J., 1974. Recherches géologiques aux confuns des chaînes ibérique et catalane (Espagne). ENADIMSA, Spain.

Canerot, J., Faure, Ph., Rahal, M., 1985a. Domnés nouvelles sur le Jurassique du Maes azgo meridional (prov. Castellón, Esapagne). C. R. Acad. Sci. Paris 298, 651-654.

Canerot, J., Faure, Ph., Rahal, M., 1985b. Massif $\mathbf{d u}$ Desierto de las Palmas (Castellón). Strata 2, 85-100

Cortés, J.E., 2001. Estratigrafia secuencial y arquitectura deposicional de los materiales carbonáticos con intercalaciones volcánicas del Jurásico Inferior y Medio de Caudiel (Castellón). DEA, Universidad Complutense, Madrid, Spain.

Enay, R., Guiraud, R., Ricou, L., Mangold, Ch., Thierry, J., Cariou, E., Bellion, Y, Dercourt, J., 1993. Callovian (162 to $158 \mathrm{Ma}$ ). In: Dercourt, J., Ricou, L.E., Vrielynck, B. (Eds.) Atlas Tethys Palaeoenvironmental Maps. BEICIP-FRANLAB, Rueil-Malmaison, pp. 81-95.

Esteban, M., Robles, S., 1979. Período preorogénico, el Mesozoico. Acta Geol. Hisp. 11, 73-78

Fernández-López, S., 1983. La Biozona Garantiana (Bajociense, Jurásico medio) en la región de Tivenys-Sierra de Cardó (Tarragona) Estud. Geol. 38, 75-93.

Fernández-López, S., 1985. El Bajociense de la Cordillera Ibérica. Ph. D. Thesis. Univ.Complutense, Madrid, Spain.

Fernández-López, S., 1991. Taphonomic concepts for a theoretical biochronology. Rev. Esp. Paleontol. 6, 37-49.

Femández-López, S., 1995. Taphonomie et interprétation des paléoenvironments. Geobios, M.S. 18, 137-154.

Fernández-López, S., 1997. Ammonites, taphonomic cycles and stratigraphic cycles in carbonate epicontinental platforms. Cuad. Geol. Ibér. 23, 95-136.

Fernández-López, S., Aurell, M., 1988. El Bajociense y Bathoniense en Ricla (Zaragoza). Cienc. Tierra 11, 251-264.

Fernández-López, S., Gómez, J.J., 1978. El Jurásico de la región de Chelva-Domeño. In: Goy, A. (Ed.), Grupo Español del Mesozoico, Jurásico Cordillera Ibérica.(Excursions Guide) vol. VII. Univ. Complutense Madrid, pp. 1-23.
Femández-López, S., Gómez, J.J., 1990a. Evolution tectono-sédimentaire et genèse des associations d'ammonites dans le secteur cen ral du Bassin Ibérique (Espagne). Cah. Univ. Cath.Lyon. 4, $39-52$.

Femández-López, S., Gómez, J.J., 1990b. Facies aalenienses y bajocienses, con evidencias de emersión y carstificación, en el sector cen de la Cuenca Ibérica, Inplicaciones paleogeográficas. Cuad. Geol. Ibér. 14, 67-111.

Femández-López, S., Gómez, J.J., 2004. The Middle Jurassic eastem margin of the Iberian platform system (eastern Spain). Riv. Ital. Paleontol. Stratigr. 110, 151-162

Femández-López, S., Meléndez, G., 1994. Abrasion surfaces on intemal moulds of ammonites as palaeobathymetric indicators. Paleogeogr. Palaeoclimatol. Palaeoecol. 110, 29-42.

Femández-López, S., Meléndez, G., 1996. Phylloceratina ammonoids in the Iberian basin during the Middle Jurassic: a model of biogeographical and taphonomic dispersal related to relative sea-level changes. Paleogeogr. Palaeoclimatol. Palaeoecol. 120, 291-302.

Femández-López, S., Mouterde, R., 1985. Le Toarcien, l'Aalénien et le Bajocien dans le secteur de Tivenys: nouvelles donnés biosratigraphiques. Strata $2,71-88$.

Femández-López, S., Meléndez, G., Suárez-Vega, L.C., 1978. El Dogger y el Malm en Moscardón (Teruel). In: Goy, A. (Ed.), Grupo Español del Mesozoico, Jurásico Cordillera Ibérica. (Excursions Guide) vol. VI. Univ. Complutense Madrid, pp. 1-20.

Femández-López, S., Gómez, J.J., Goy, A., 1985. Le Dogger de Caudiel (Castellón): Sédimentologie des carbonates développés sur un "monticule" de matériaux volcaniques. Strata 2, 101-115.

Fernández-López, S., Aurell, M., García Joral, F., Gómez, J.J., Henriques, M.H.P., Martínez, G., Meléndez, G., Suárez-Vega, L.C., 1996. El Jurásico Medio de la Cuenca Catalana: unidades litoesratigráficas y elementos paleogeográficos. Rev. Esp. Paleontol Spec., 122-139

Femández-López, S., García Joral, F., Gómez, J.J., Henriques, M.H.P., Martínez, G., 1998. La diferenciación paleogeográfica de la Cuenca Catalana al principio del Jurásico Medio. Rev. Soc. Geol. Esp. 11, 3-22.

Friebe, A., 1995. Die schwammfazies im Mittlejura des nordöstlichen Keltibericums (Spanien). Profile 8, 239-279.

Gaibar-Puer C., Geyer, O.F., 1967. Estratigrafia del Jurásico y liásico en el sector de Yémeda (borde SW. de la Cordillera Ibérica). Acta Geol. Hisp. 2, 89-92.

Gaibar-Puer C., Geyer, O.F., 1969. Estratigrafia, edad y espesor atribuibles al Jurásico Manchego y sus relaciones con algunos sectores de la Cordillera Ibérica. Bol. Geol. Min. 84, 1-44.

Gautier, F., 1968. Sur l'existence et l'âge d'un paléovolcanisme dans le Jurasique Sud-aragonais (Espagne). C. R. Somm. Soc. Géol. Fr. $3,74-75$.

Gautier, F., 1974. Mapa y memoria de la hoja de Camarena de la Sierra (613) del Mapa Geológico Nacional. IGME, Madrid. 24 pp.

Geyer, -F., Behmel, H., Hinkelbein, H., 1974. Die Grenzoolite im Jura von Astpanien. Neues. Jb. Geol. Paläontol. Abh. 143, 17 -57.

Gómez, J.J., 1979. El Jurásico en facies carbonatadas del Sector Levantino de la Cordillera Ibérica, Seminarios de Estratigrafía. Serie Monogr. 4, 1-683.

Gómez, J.J., 1985a. Sedimentología y paleogeografia del Jurásico en la hoja geológica $n^{\bullet} 55$ (7-7), Llíria, del Mapa Geológico de España a escala de 1:200.000. IGME, Madrid, 37-60.

Gómez, J.J., 1985b. Sedimentología y paleogeografía del Jurásico Inferior y Medio en la hoja geológica $n^{\bullet} 47$ (7-6), Teruel, del Mapa Geológico de España a escala de 1:200.000. IGME, Madrid, 47-72. 
Gómez, J.J., 1991. Sedimentología y paleogeografía del Jurásico en la hoja geológica $n^{\bullet} 4$ (7-5), Daroca, del Mapa Geológico de España a escala de $1: 200.000$. ITGE, Madrid, 31-82.

Gómez, J.J., Fernández-López, S., 1994. Condensation processes in shallow platforms. Sediment. Geol. 92, 147-159.

Gómez, J.J., Fernández-López, S., 2004a. Las unidades litoestratigráficas del Jurásico Medio de la Cordillera Ibérica. Geogaceta 35, $91-94$.

Gómez, J.J., Fernández-López, S.R., 2004b. Jurásico Medio. In: Vera, J.A. (Ed.), Geología de España. SGE-IGME, Madrid, Spain, pp. 500-503.

Gómez, J.J., Goy, A., 1979. Las unidades litoestratigráficas del Jurásico medio y superior en facies carbonatadas del Sector Levantino de la Cordillera Ibérica. Estud. Geol. 35, 17-57.

Gómez, J.J., Trell, A., Pérez, P., 1976. Presencia y edad de vulcanitas en el Jurásico del Norte de Valencia (Cordillera Ibérica, España). Acta Geol. Hisp. 11, 1-7.

Hinkelbein, K., 1975. Beiträge zur stratigraphie und paläontologie des Juras von Astpanien: VII. Stratigraphie und Fazies in Mittel jura der centralen Iberischen Ketten. Neues Jb. Geol. Paläontol. Abh. $148,139-184$

Knaust, D., Hauschke, N., 2004. Trace fossils versus pseudof ossils in Lower Triassic playa deposits, Germany. Palaeogeogr. Palaeoclimatol. Palaeoecol. 215, 87-97.

Lanaja, J.M., 1987. Contribución de la exploración petrolífera al conocimiento de la geología de España. IGME, Madrid.

Maldonado López, A., Alonso Martínez, B., Díaz Guerrero, J.I., Ferrán Vert, M., Giró Molner, S., Vázquez Martínez, A., 1986. Mapa geológico de la plataforma continental española y zonas adyacentes. Escala 1:200.000, 41-42, Tortosa-Tarragona. IGME, Madrid.

Martínez González, R.M a ., Lago San José, M., Valenzuela Ríos, J.I., Vaquer Navarro, Salas, R., Dumirrescu, R., 1997. El volcanismo Triásico y Jurásico del sector SE de la Cadena Ibérica y sus relaciones con los estadios de rift mesozoicos. Bol. Geol. Min. $108,367-376$.

Martínez González, R.Mª Vaquer Navarro, R., Lago San José, M., 1998. El volcanismo jurásico de la Sierra de Javalambre (Cadena Ibérica, Teruel). Teruel 86, 43-61.

Meléndez, G., 1989. El Oxfordiense en el Sector Central de la Cordillera Ibérica. Institución "Fernando el Católico". Instituto de Estudios Turolenses, Zaragoza.

Morillo-Velarde, M.J., Meléndez-Hevia, F, 1981. El Jurásico de "La Alcarria"-"La Mancha". Cuad. Geol. -Univ. Granada 10, $149-166$

Mouterde, R., Fernández-López, S., Goy, A., Linares, A., Rivas, P., Ruget, Ch., Suárez-Vega, L.C., 1978. El Jurásico de la región de bón. (Teruel). In: Goy, A. (Ed.), Grupo Español del Mesozoico, Jurásico Cordillera Ibérica. Universidad Complutense, Madrid (Excursions Guide), vol. II, pp. 1-13.

-livero, D., 2003. Early Jurassic to Late Cretaceous evolution of Zophyces in the French Subalpine basin (southeastern France) Palaeogeogr. Palaeoclimatol. Palaeoecol. 192, 59-78.
Ortí, F., Vaquer, R., 1980. Volcanismo Jurásico del sector valenciano de la Cordillera Ibérica, Distribución y rama estuctural. Acta Geol. Hisp. 15, 127-130.

Robles Orozco, S., 1974. Estudio geológico del Macizo del Cardó y sectores adyacentes. Ph. D. Thesis, Univ. Autonoma, Barcelona. Spain.

Salas, R., Casas, A., 1993. Mesozoic extensional tectonics, stratigraphy and crustal evolution during the Alpine cycle of the eastem Iberian basin. Tectonophysics 228, 33-55.

Salas, R., Guimerá, J., Mas, R., Martín-Closas, C., Meléndez, A., Alonso, A., 2001. Evolution of the Mesozoic Central Iberian Rift System and its Cainozoic inversion (Iberian Chain). In: Ziegler, P.A., Cavazza, W., Robertson, A.H.F., Crasquin-Soleau, S. (Eds.), Peri-Tethys Memoir 6: Peri-Tethyan Rift Wrench Basins and Passive Margins. Mém. Mus. natn. Hist. Nat. 186, Paris, France, pp. 145-185.

Sequeiros, L., Meléndez, G., 1987. El Calloviense de los Ibérides (Dominio Ibérico, España). Síntesis bioestratigráfica. Estud. Geol. 43, 95-105.

Sequeiros, L., Cólera, I., Valenzuela, R., Sánchez, I., 1978. Bioestratigrafía del Jurásico (Lias y Dogger) en el sector Belchite-Almonacid de la Cuba (prov. de Zaragoza, Cordillera Ibérica). Estud. Geol. 34, 293-298.

Stampfli, G.M., Borel, G.D., 2004. The TRANSMED Transects in Space and Time: Constraints on the Paleotectonic Evolution of the Mediterranean Domain. In: Cavazza, W., Roure, F.M., Spakman, W., Stampfli, G.M., Ziegler, P.A., 2004. The 'TRANSMED Atlas-The Mediterraean Region from Crust to Mantle. Springer Berlin Heidelberg New York, pp. 53-80 and CD-ROM.

Stoeckinger, W.T., 1976. Valencian gulf offer deadline nears. il Gas J. 29, 197-204.

Thierry, J., 2000. Middle Callovian (157-155 Ma). In: Decourt, J., Gaetani, M., Vrielynck, B., Barrier, E., Biju-Dubal, B., Brunet, M.F., Cadet, J.P., Crasquin, S., Sandulescu, M. (Eds.), Peri-Tethys Atlas. Paleogeographical Maps. Commission for the Geologic Map of the World. Paris, France, pp. 71-82.

Vera, J.A., 2001. Evolution of the South Iberian Continental Margin. In: Ziegler, P.A., Cavazza, W., Robertson, A.H.F., CrasquinSoleau, S. (Eds.), Peri-Tethys Memoir 6: Peri-Tethyan Rift' Wrench Basins and Passive Margins. Mém. Mus. natn. Hist. Nat. 186, Paris, France, pp. 51-108.

Vera, J.A. (Ed.), 2004. Geología de España. SGE-IGME, Madrid.

Vera, J.A., Salas, R., Bitzer, K. 2001 . Ba jocian-Bathonian. Iberian and Western Mediterranean. In: Stampfli, G., Borel, G., Cavazza, V., Mosar, J., Ziegler, P.A. (Eds.), The Paleotectonic Atlas of the PeriTethyan Domain. European Geophysical Society.

Viallard, P., 1973. Recherches sur le cycle Alpin dans la Chîne Ibérique Sud-occidentale. Ph. D. Thesis, Univ. Toulouse, France.

Ziegler, P.A., 1990. Geological Atlas of Westem and Central Europe, 2nd edition. Shell Internationale Petroleum Maatschappij. Amsterdam. 